\title{
AN ORCHID INVENTORY AND CONSERVATION PROJECT AT BOSQUE DE PAZ BIOLOGICAL RESERVE, UPPER RIO TORO VALLEY, ALAJUELA, COSTA RICA
}

\author{
Melania MuÑoz ${ }^{1,3}$ \& StePhen H. KiRBY ${ }^{2}$

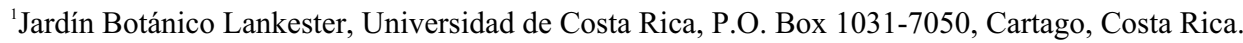 \\ ${ }^{2}$ U.S. Geological Survey, Menlo Park, California 94025, U.S.A. \\ ${ }^{3}$ Author for correspondence: melaniamunozg@yahoo.com
}

\begin{abstract}
RESUMEN. El Jardín de Orquídeas de la reserva fue creado en el año 2000. Allí, las orquídeas caídas de los árboles del bosque son rescatadas, reubicadas y conservadas en árboles vivos (principalmente güitite, jaul y poró). Los objetivos del proyecto son: aumentar el conocimiento de la diversidad de orquídeas de la Cuenca del Río Toro mediante un inventario, respaldado por fotografías y material de herbario seco y en líquido, de las orquídeas rescatadas del bosque y cultivadas en el Jardín de la reserva y dar a conocer dicha reserva como ejemplo de ecoturismo educativo y sitio de gran importancia para la investigación orquideológica. El inventario se ha llevado a cabo desde junio del 2004. Se han identificado 47 géneros y 163 especies; 12 de éstas son endémicas de Costa Rica. En promedio, se observan 40 especies en floración cada mes. El hecho de que el Jardín de Orquídeas está situado junto a una reserva de vegetación natural, es una ventaja que puede aprovecharse para investigar sobre taxonomía y ecología de orquídeas de la región. Además de las opciones de investigación, Bosque de Paz realiza una importante labor en educación ambiental. Este inventario y la colección de herbario resultante son herramientas importantes para la investigación en orquideología. Consultar una colección de este tipo es de mucha utilidad tanto para estudios taxonómicos como ecológicos, en vista de que pocas veces se cuenta, como en este caso, con observaciones de plantas vivas, datos fenológicos, fotografías y material preservado, al mismo tiempo.
\end{abstract}

Orchids are among of the best-known and beloved plants, not only by scientists, but also by amateurs, and have a high commercial demand thanks to their beautiful, diverse and interesting flowers (Herrera 1998). It is the largest family of flowering plants in the world, with around 20,000 species (Dressler 1993). In Costa Rica there are around 1,400 registered species of orchids, but the knowledge of this family has grown a lot in recent years. Since 1993, around 20 new species have been described each year, and their classification is constantly changing because of molecular studies (Dressler 2003).

On the other hand, orchids are one of the most threatened groups of plants. Many species are considered endangered (Salazar 1996, Morales 2000). Most of the Orchidaceae family is included in the Appendices of the Convention on International Trade in Endangered Species of Wild Fauna and Flora (CITES), which main objective is to regulate international trade to prevent species extinction because of this trade (or their overexploitation) (von Arx 1996).
Human activities have been causing, directly or indirectly, a decrease in orchid population sizes. The habitat alteration, including total destruction, modification and fragmentation, is the main problem for the conservation of the diversity. Most of the tropical orchids grow in primary forests. Some species are probably more tolerant to forest fragmentation than others; hence those less tolerant populations will decline more rapidly when habitats are altered. Another important threat is the illegal exploitation. A lot of plants are illegally collected from nature and sold (Salazar 1996, Morales 2000).

The main requirement for orchid conservation is therefore the maintenance of natural habitats (Light 2000, Catling 1996). The objective of in situ conservation is to allow species to be in the habitat where they belong and in the environment to which they are adapted (BGCI 1989). Ex situ conservation is the maintenance of organisms out of their natural habitat, for example in botanical gardens, field collections, and others, and its objective is to ensure the conserva- 
tion of endangered species. Ex situ conservation is justifiable only when it is part of an integral conservation strategy (BGCI 1989).

The establishment of small natural reserves, sustained by private institutions, is an important strategy that complements the effort of the State to create and maintain the National Park System. In this way, a coordinated effort is made to conserve the Costa Rican natural and cultural patrimony (Fournier and Herrera 1979). Bosque de Paz is a private biological reserve located in the Central Volcanic Range. It has both primary and secondary forests, as well as grazing and in various states of reforestation (Kirby 2003). The Reserve was created with the objective of protecting the flora and fauna of the zone, and to create public awareness of the importance of conservation. The idea to relocate orchids for public viewing and scientific study began in the mid-90's. After major storms with high winds and heavy rain occur, large number of branches and trees, full of epiphytic plants, fell across $20 \mathrm{~km}$ of trails in the Reserve. These orchids would die eventually due to low light and high humidity conditions. Fallen plants were subsequently rescued, and some of the orchid diversity of the area is now made accessible to visitors (Kirby 2003). In 1996 the Reserve had orchids relocated at eye level on trees along a 75 meter-long trail. In 2000, the Orchid Garden was created, at an elevation of about 1,550 meters above sea level, at $10^{\circ} 12.425^{\prime}$ $\mathrm{N}$ latitude and $84^{\circ} 19.140^{\prime} \mathrm{W}$ longitude. The orchids are located on trees and live trunks.

To preserve orchid diversity, it is necessary to know which species exist, where they are located and basic aspects about their ecology and frequency in nature (Dressler 1996). Ideally, live plants in collections should be studied, but not every grower knows where their plants come from. In practice, one of the most common ways to obtain this kind of information is by visiting museums and herbariums, where dry material, sometimes complemented with flowers preserved in alcohol, can be found (Dressler 1996). Moreover, more elaborate surveys that give diversity, endemism, density and blooming data of the orchids present in a specific area, are even more valuable because they increase the knowledge of the distribution and ecology of the species, especially the rare ones (Soto 1996).
Surveys of plants present in National Parks, botanical gardens, as well as that of the biological preserves and private collections, are essential for the use of these places in conservation and research. Because of this, it is important to perform both taxonomic studies as sources of information about the species diversity in different places of the country, and ecological studies to know the habitat and the environmental conditions where the native orchids grow, as well as obtaining fundamental information on orchid biogeography (Kirby this volume). This study is believed to be the first comprehensive, multi-year collection, description and identification of orchids in the Central Volcanic Range in Costa Rica. The objective of this paper is to provide a species inventory of native orchids from the Río Toro Valley, Valverde Vega, Alajuela, as a baseline for conservation and starting point for orchid research in this region.

\section{Methodology}

An orchid survey at Bosque de Paz Biological Reserve has been in progress since June of 2004. Monthly field trips to the Reserve were made in order to sample blooming species. A herbarium collection was created and is currently maintained at the Reserve. Flowers were collected and preserved in liquid (55\% alcohol, 5\% glycerin and $40 \%$ water) as well. Every species was photographed and described using the checklist described by Kirby and Muñoz (this volume). Nomenclature follows that used by Dressler (2003). The blooming dates of every species were recorded and the identified plants were all labeled in the Orchid Garden.

\section{Results}

In the study period, 163 orchid species were observed in bloom and described, of which 12 species are endemics to Costa Rica. These were distributed into 47 genera. The genera with greatest number of species in the garden are: Epidendrum (24 spp.), Pleurothallis (23 spp.), Maxillaria (22 spp.) Stelis (10 spp.), Lepanthes (8 spp.), Masdevallia (7 spp.), Prosthechea (6 spp.), Elleanthus (5spp.), Platystele (4 spp.) and Scaphyglottis (4 spp.) (Table 1). On average, $40( \pm 11)$ species were observed in bloom each month. The months with more species in bloom were October, November and 
Table 1. Orchid list of Bosque de Paz Biological Reserve.

\begin{tabular}{|c|c|c|c|}
\hline Name & Field number & Name & Field number \\
\hline Acineta densa & 04_98 (97) & Masdevallia sp. & $06 \_240$ \\
\hline Ada chlorops ${ }^{a}$ & 04_105 & Masdevallia calura $\mathrm{E}$ & $04 \_80$ \\
\hline & 04126 & Masdevallia chontalensis & 05_205 \\
\hline $\begin{array}{l}\text { Barbosella dollchorniza" } \\
\text { Rrassia arcuigera }\end{array}$ & $04+120$ & Masdevallia nidifica & $06 \_212$ \\
\hline Brassia arcuigera & 05_174 & Masdevallia picturata & $06 \_234$ \\
\hline Chondrorhyncha picta ${ }^{a}$ & 04_100 & Masdevallia pygmaea & 06_228 \\
\hline Cryptocentrum calcaratum & 04_104 & Masdevallia striatella ${ }^{a}$ & $04 \_131$ \\
\hline Dichaea glauca $^{a}$ & 04_147 & \multirow{3}{*}{ Maxillaria (5 spp.) } & \multirow{3}{*}{$\begin{array}{c}04 \_96^{a} / 05 \_189 / 06 \_213 / \\
06 \_227 / 06 \_237 /\end{array}$} \\
\hline Dichaea schlechteri $\mathrm{E}$ & $04 \_128$ & & \\
\hline Dichaea trichocarpa & 04_75 & & \\
\hline Dracula carlueri & $05 \_175$ & Maxillaria angustisegmenta $a$ & 04_110 \\
\hline Elleanthus (2spp.) & 06_220/06_238 & Maxillaria biolleyi & 04_146 \\
\hline Elleanthus cynarocephalus & $-04 \_77^{-}$ & Maxillaria bradeorum & 05_163 \\
\hline Elleanthus glaucophyllus & $05 \_173$ & Maxillaria brevilabia & 04_148 \\
\hline Elleanthus lancifolius ${ }^{a}$ & $05 \_180$ & Maxillaria cucullata & 04_140 \\
\hline Encyclia ceratistes & $04 \_82$ & Maxillaria dendrobioides ${ }^{a}$ & 04_141 \\
\hline Epidendrum (8 spp) & $\begin{array}{c}04 \_115^{a} / 04 \_156 / 05 \_177 / \\
05-187 / 06 \_210 / 06 \_216 / \\
06221 / 06236 /\end{array}$ & $\begin{array}{l}\text { Maxillaria flava } \\
\text { Maxillaria fulgens } \\
\text { Maxillaria inaudita }\end{array}$ & $\begin{array}{c}06 \_235 \\
04 \_74 \\
04 \_145\end{array}$ \\
\hline Epidendrum firmum & $04 \_136$ & Maxillaria microphyton $^{a} \mathrm{E}$ & 05_176 \\
\hline Epidendrum lacustre & $\bar{b}$ & Maxillaria nasuta & 04_123 \\
\hline Epidendrum lancilabium & 05_204 & Maxillaria porrecta & $04 \_125$ \\
\hline Epidendrum laucheanum & $04 \_93$ & Maxillaria pseudoneglecta ${ }^{a}$ & $04 \_127$ \\
\hline Epidendrum myodes & $05-184$ & Maxillaria ringens & 04_124 \\
\hline Epidendrum palmense $\mathrm{E}$ & $05 \_162$ & Maxillaria sigmoidea & 06_239 \\
\hline Epidendrum parkinsonianum & $04 \_157$ & Maxillaria umbratilis & 06_208 \\
\hline Epidendrum piliferum & 04 & Maxillaria wercklei E & 05_192 \\
\hline Epidendrum platystigma $\mathrm{E}$ & $05-181$ & Miltoniopsis warscewiczii & 04_132 \\
\hline Epidendrum radicans & $04 \_154$ & Oerstedella endresii & 04_143 \\
\hline \multirow{2}{*}{ Epidendrum sancti-ramoni ${ }^{a}$} & \multirow{2}{*}{$05 \_161$} & Oerstedella exasperata & 04_70 \\
\hline & & Oerstedella intermixta $\mathrm{E}$ & 04_107 \\
\hline $\begin{array}{l}\text { Epidendrum subnutans }{ }^{a} \mathrm{E} \\
\text { Enidendrum summerhavesii }\end{array}$ & 04_137(155) & Oncidium & 04_152 \\
\hline & $05-186$ & Oncidium bracteatum & $04 \_81(83)$ \\
\hline Epidendrum wercklei & $\mathrm{b}$ & Oncidium klotzschianum & $\overline{04} \_129$ \\
\hline Erythrodes killipii & $06 \_215$ & Oncidium panduriforme $e^{a}$ & 04_85 \\
\hline Eurysyles standleyi $\mathrm{E}$ & $07 \_243$ & Osmoglossum egertonii & 04_134 \\
\hline Gongora horichiana & $04 \_112$ & Otoglossum chiriquense & $06 \_232$ \\
\hline Govenia quadriplicata & $06 \_224$ & Phragmipedium longifolium ${ }^{a}$ & 04_92 \\
\hline Houlletia tigrina & $06 \_231$ & Platystele compacta & $04 \_89$ \\
\hline \multirow[t]{3}{*}{ Lepanthes (7spp.) } & $\begin{array}{c}04 \_130 \\
05 \quad 158 / 05 \quad 164 / 05 \quad 190 /\end{array}$ & Platystele lancilabris $^{a} \mathrm{E}$ & $05 \_166$ \\
\hline & $06 \_207 / 06 \_214 / 06 \_217 /$ & Platystele oxyglossa $a^{a}$ & 04_103 \\
\hline & $06 \_219 /$ & Platystele propinqua $^{a} \mathrm{E}$ & 04_113 \\
\hline Lepanthes crossota & 04_114 & \multirow[t]{4}{*}{ Pleurothallis (10 spp.) } & $04 \_101^{a} / 04 \_116^{a /}$ \\
\hline Lockhartia hercodonta & $06 \_241$ & & 04_120/04_139/04_153/ \\
\hline Lockhartia oerstedii & 04_102 & & 05-188/06_211/06_218/ \\
\hline Lockhartia oerstedii ${ }^{a}$ & 05_178 & & 06_230/ $06 \_24 \overline{2 /}$ \\
\hline Lycaste macrophylla & 04_99 & Pleurothallis amparoana ${ }^{a}$ & 05_171 \\
\hline
\end{tabular}

$\mathrm{E}=$ Endemic species to Costa Rica. ${ }^{\mathrm{a}}=$ Samples with duplicates in the Herbarium of the University of Costa Rica. ${ }^{\mathrm{b}}=$ Not collected plants, just identified in the Orchid Garden. 
TABLE 1 (continuation). Orchid list of Bosque de Paz Biological Reserve.

\begin{tabular}{|c|c|c|c|}
\hline Name & Field number & Name & Field number \\
\hline Pleurothallis cardiothallis ${ }^{a}$ & 04_108 & Scaphyglottis pachybulbon ${ }^{a}$ & 04_149 \\
\hline Pleurothallis costaricensis ${ }^{a}$ & 05_165 & Scaphyglottis pulchella & $04 \_84$ \\
\hline Pleurothallis dentipetala & 05_203 & Scaphyglottis sigmoidea ${ }^{a}$ & $04 \_86$ \\
\hline Pleurothallis eumecocaulon & $04 \_133$ & Sigmatostalix picta & $04 \_90$ \\
\hline Pleurothallis johnsonii & $04 \_117$ & Sobralia amabilis & $06 \_233$ \\
\hline Pleurothallis palliolata & 05_202 & Sobralia leucoxantha & $06 \_225$ \\
\hline Pleurothallis phyllocardioides ${ }^{a}$ & $04 \_118$ & Solenocentrum costaricense & $04 \_76$ \\
\hline Pleurothallis pompalis ${ }^{a}$ & $04 \_88$ & Stanhopea costaricensis & $06 \_226$ \\
\hline Pleurothallis ramonensis $\mathrm{E}$ & $04 \_87$ & Stelis (8 spp). & $04 \_142 / 04 \_144 / 05 \_167^{a} /$ \\
\hline Pleurothallis ruscifolia & $04 \_72$ & & $05 \_170 / 05 \_174 / 05-182 /$ \\
\hline Pleurothallis tonduzii ${ }^{a}$ & 04995 & & $05-183 / 05-185$ \\
\hline Prosthechea sp. & 06_206 & Stelis gracilis $^{a}$ & 04_109 \\
\hline Prosthechea brassavolae ${ }^{a}$ & 04_106 & Stelis ovatilabia & $04 \_119$ \\
\hline Prosthechea campylostalix ${ }^{a}$ & $05 \_168$ & Systeloglossum costaricense & 06_229 \\
\hline Prosthechea ionocentra & $04 \_94$ & Telipogon biolleyi & $04 \_71$ \\
\hline Prosthechea pseudopygmaea & $04 \_138$ & Trichopilia marginata & 06_209 \\
\hline Prosthechea vespa & 05_193 & Trichopilia suavis & 04_122 \\
\hline Restrepia muscifera $^{a}$ & $04 \_135$ & Trichosalpinx sp. & $06 \_216$ \\
\hline Restrepia trichoglossa & $04 \_121$ & Trichosalpinx memor & $05 \_159$ \\
\hline Rossioglossum schlieperianum & 05_179 & Trichosalpinx memor & 05_160 \\
\hline Salpistele brunnea & 05_191 & Warszewiczella discolor & 04_150 \\
\hline Scaphosepalum anchoriferum & $04+79$ & Xylobium elongatum & $04 \_111$ \\
\hline Scaphyglottis densa ${ }^{a}$ & 05_169 & Xylobium sulfurinum & $04+73$ \\
\hline
\end{tabular}

$\mathrm{E}=$ Endemic species to Costa Rica. ${ }^{\mathrm{a}}=$ Samples with duplicates in the Herbarium of the University of Costa Rica. ${ }^{b}=$ Not collected plants, just identified in the Orchid Garden.

December (Fig. 1). Dried herbarium sheets were prepared from plants and flowers of 149 species and flowers from 139 species were preserved by pickling. Duplicates of 36 species were deposited in the Herbarium of the University of Costa Rica (USJ).

\section{Discussion}

Having more than 160 species registered so far, with at least 12 being endemic, Bosque de Paz can now be recognized as a key site for in situ conservation of orchids in Costa Rica. With an area of 2000 hectares and with elevations ranging between 1,300 and 2,450 meters, the Reserve brings a big, little fragmented area, with modest human impact and with several microhabitats that support the existence, reproduction and other natural biological processes of an important number of orchids.

Bosque de Paz is a natural reserve, which has had success in the conservation of a group of plants as vul- nerable as orchids. This also reflects success in the conservation of other plant families present in the zone. Moreover, the Orchid Garden could be considered a potential bank of germoplasm in the field (BGCI 1989). Field collections like this are better than conventional ones, because they have very similar characteristics to the natural habitat. The relocated plants have similar elevation, rainfall, temperature and pollinators where they were found. According to BGCI (1989) such collections should be the main ex situ conservation strategy. The Garden is located just next to an important natural forest, which is an advantage that could be further exploited for the taxonomic, ecologic and biogeografic studies of the region. Since it is the first multi-year orchid survey in the Central Volcanic Range, it is a starting point for comparisons with other montane cloud-forest environments in Costa Rica and elsewhere in Latin America (see Kirby, this volume).

Furthermore, one of the most important roles of 


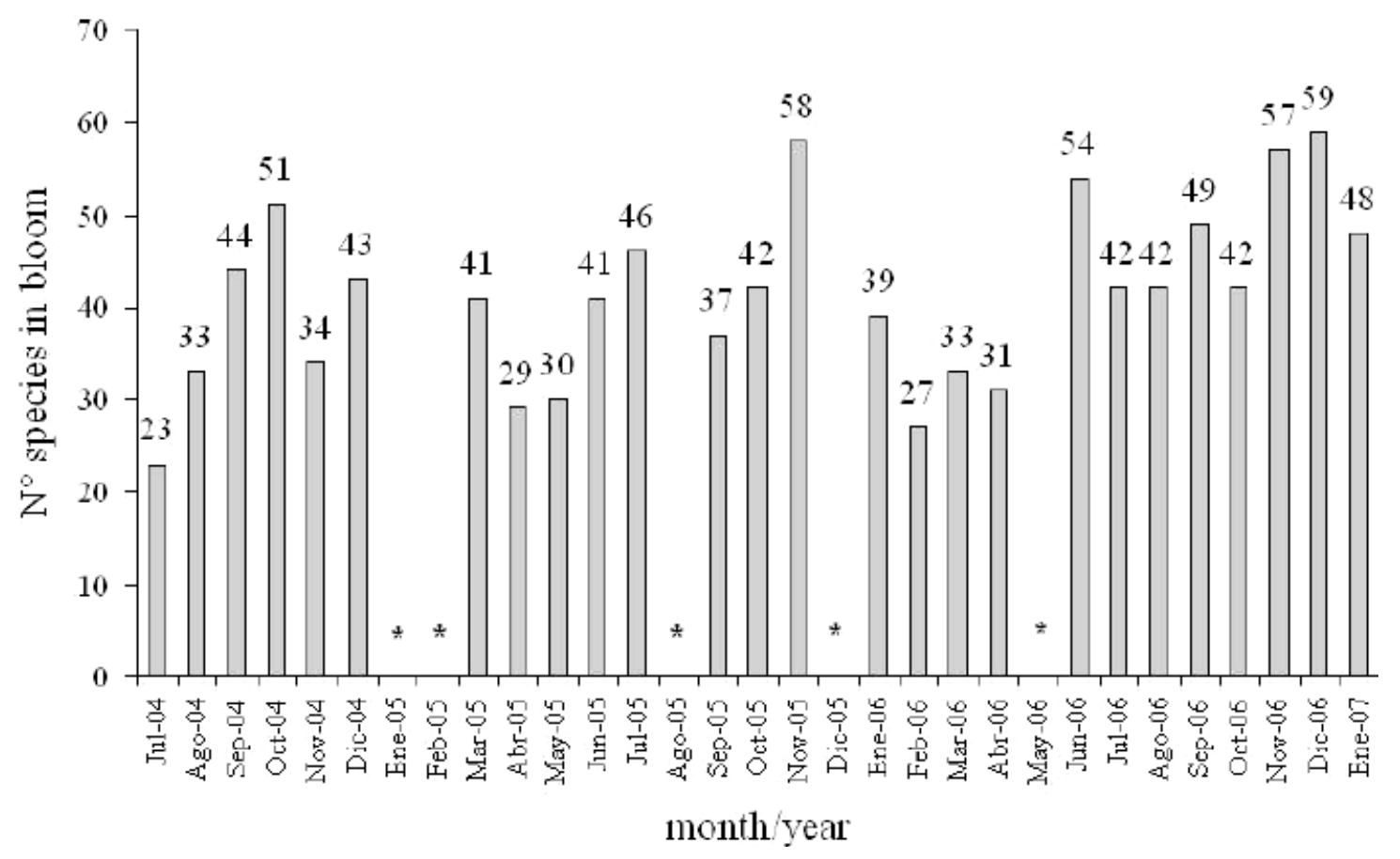

Figure 1. Number of species observed in bloom from July 2004 to January 2007 in the Orchid Garden of Bosque de Paz Reserve. *Data not collected.

natural preserves is to educate the people who visit them (Head and Lauer 1996). The creation of an orchid garden is therefore important for environmental education of both national and foreign tourists, because thanks to it, there is a great number and diversity of blooming orchid species that can be easily seen in the garden throughout the year, and are difficult to observe in their natural habitat. This educational opportunity helps to create consciousness about Costa Rica's natural richness, the enormous orchid diversity, the problems that make their conservation difficult, and that everybody can do something for their protection, such as the simple action of not taking them from their natural habitats.

Orchid surveys such this one are also valuable tools for orchid scientists. High-resolution digital and printed photographs, high quality herbarium samples, both dry and pickled specimens, with duplicates in the Herbarium of the University of Costa Rica (USJ) are provided. Access to a collection like this one could be very useful to researchers for taxonomic studies, for which there is limited preserved material, especially for those less conspicuous and rare species. Accurate species identifications also will be useful for population studies and orchid biogeography.

To conclude, Bosque de Paz Biological Reserve reflects the great orchid diversity of the area. Moreover, the reserve's Orchid Garden is a very important place for conservation, research and environmental education in several fields, with an obvious emphasis in orchideology.

ACKNOwLEDGMENTS. The authors wish to thank Carlos O. Morales and Robert Dressler for their generous help in the identification of some species. To Piero Protti for his help in the field collection, preparation of the herbarium material, and in the elaboration and advice for this paper. To Vinicio Porras for his help in the field and the Orchid Garden maintenance. This project is made possible by the support of Bosque de Paz Biological Reserve.

\section{LiterATURE CITED}

BGCI (Botanical Gardens Conservation International). 1989. La estrategia de los Jardines Botánicos para la Conservación. BGCI, WWR y UICN. Suiza. 51 p. 
Catling, P.M. 1996. Conservation Strategy: In situ conservation. Pp. 15-23. In: E. Hágsater \& V. Dumont (eds.). Orchids - Status Survey and Conservation Action Plan. IUCN. Gland Switzerland and Cambridge, UK.

Dressler, R.L. 1993. Phylogeny and Classification of the Orchid Family. Dioscorides Press. Hong Kong. 314 p.

Dressler, R.L. 1996. The problems associated with botanical sampling and study. P. 34 in: E. Hágsater \& V. Dumont (eds.). Orchids- Status Survey and Conservation Action Plan. IUCN. Gland, Switzerland and Cambridge, UK.

Dressler, R.L. 2003. Orchidaceae. In: Hammel, B. E., Grayum, M. H., Herrera, C. \& Zamora, N. (eds.). Manual de Plantas de Costa Rica, vol III: Monocotiledóneas (Orchidaceae-Zingiberaceae). Missouri Bot. Gard. INBio. Museo Nacional de Costa Rica. Pp. 1-595.

Fournier, L.A. \& M.E. Herrera. 1979. Importancia científica, económica y cultural de un sistema de pequeñas reservas naturales en Costa Rica. Agron. Costarr. 3(1): 53-55. Head, C. \& A. Lauer. 1996. Conservation Strategy: Education. Pp. 46-47 in: E. Hágsater \& V. Dumont (eds.). Orchids - Status Survey and Conservation Action Plan. IUCN. Gland Switzerland and Cambridge, UK.

Herrera, A. 1998. Factibilidad técnica y financiera para la producción in vitro de orquídeas (Masdevallia calura y Masdevallia reichenbachiana) en Monteverde, Puntarenas. Tesis de Licenciatura en Economía Agrícola, Universidad de Costa Rica, San José. 149 p.

Kirby, S.H. 2003. Neotropical orchid eco-tourism: educa- tional experience of an orchid neophyte at The Bosque de Paz Biological Preserve, Central Volcanic Range, Costa Rica. Lankesteriana 7: 121-124.

Kirby, S.H. 2007. Geological Processes and Orchid Biogeography with Applications to Southeast Central America. Proceedings of the $3^{\text {rd }}$ International Orchid Conservation Congress in Lankesteriana, this volume.

Kirby, S.H. \& M. Muñoz. 2007. A form and checklist for the description of orchids in the field and laboratory work. Costa Rica. Proceedings of the $3^{\text {rd }}$ International Orchid Conservation Congress in Lankesteriana, this volume.

Light, M.H.S. 2000. In situ orchid conservation: challenge and opportunity. Orchid Conserv. News 3: 4-5.

Morales, J.F. 2000. Orquídeas, cactus y bromelias del bosque seco. INBio. Santo Domingo de Heredia, Costa Rica. $162 \mathrm{p}$.

Salazar, G.A. 1996. Conservation Threats. Pp. 6-10 in: E. Hágsater \& V. Dumont (eds.). Orchids- Status Survey and Conservation Action Plan. IUCN. Gland, Switzerland and Cambridge, UK.

Soto, M. 1996. Conservation Strategy: The importance of research. Pp. 33-38. In: E. Hágsater \& V. Dumont (eds.). Orchids - Status Survey and Conservation Action Plan. IUCN. Gland, Switzerland and Cambridge, UK.

von Arx, B. 1996. Conservation Strategy: International Protection. Pp. 11-14. In: E. Hágsater \& V. Dumont (eds.). Orchids - Status Survey and Conservation Action Plan. IUCN. Gland, Switzerland and Cambridge, UK.

Melania Muñoz earned her B.S. in Biology at the University of Costa Rica in 2003. She is currently working on her Master's degree in Biotechnology at the same University. Her research involves both population genetics and in vitro culture of orchids. She is also a research assistant at the Lankester Botanical Garden. She has been the biologist in charge of the inventory of the Orchid Garden and the preparation and maintenance of the herbarium material at Bosque de Paz Biological Reserve since 2004.

Stephen H. Kirby was awarded a Ph.D. in Geology in 1975 from the University of California at Los Angeles. He has been employed by the U.S. Geological Survey since 1968 and is currently a Research Geophysicist and Senior Scientist in the Earthquake Hazard Team in Menlo Park, California. He is a fellow of the American Geophysical Union and the Mineralogical Society of America. He is an author of more than 160 peer-reviewed papers and book chapters and has worked as a volunteer at the Bosque de Paz Biological Reserve since 2002. 